\title{
ENTRE O DESISTIR E O RESISTIR: NOTAS SOBRE O COTIDIANO DOCENTE NA EDUCAÇÃO SUPERIOR
}

BETWEEN GIVING UP AND WITHSTANDING: NOTES ON EVERYDAY TEACHING IN SUPERIOR EDUCATION

\section{ENTRE DESISTIR Y RESISTIR: NOTAS SOBRE LA ENSEÑANZA DIARIA EN LA EDUCACIÓN SUPERIOR}

Simone Mainieri Paulon*

Ariadne Cedraz ${ }^{*}$

\begin{abstract}
RESUMO
O artigo intenta evidenciar uma dimensão sensível das práticas educacionais, por meio de uma estilística não estandardizada de produção de conhecimento. O texto-script permeia o fazer artístico de uma atriz, ao mesmo tempo em que revela o palco-sala de aula onde se encena o fazer docente, corporificando dilemas existenciais contemporâneos do trabalho com educação. $\mathrm{O}$ exercício da escrita ficcional, como propõem Bottoni e Costa, configura a estratégia metodológica que costura o estudo. Esta estratégia objetiva revelar paradoxos de uma prática profissional diante do niilismo predominante que toma os corpos dos atores, no contexto definido por Han como "sociedade do cansaço". Como criar movimentos de resistência onde apenas parece haver cansaço? Como inventar linhas de fuga quando tudo parece convidar à desistência? Esses são os questionamentos que se insinuam ao longo do enredo, chamando à análise acerca do educar em tempos que não somente convidam à desistência, mas também incitam resistências.
\end{abstract}

Palavras-chave: Narrativa ficcional. Niilismo. Resistência. Trabalho docente. Criação.

\section{ABSTRACT}

This study aims to bring into evidence a sensitive dimension of educational practices, through a non-standardized style of knowledge production. The text-script permeates an actress' artistic performance while unveiling the stage-classroom where teaching is performed, embodying contemporary existential dilemmas pertaining to working with education. The exercise of fictional writing, as proposed by Bottoni and Costa, sets up the methodological strategy that interweaves this study. This strategy aims to

"Professora no Pós-Graduação em Psicologia Social da Universidade Federal do Rio Grande do Sul (UFRGS). E-mail: simonepaulon@gmail.com.

**Doutoranda no Pós-Graduação em Psicologia Social da UFRGS. E-mail: dinecedraz@yahoo.com.br. 
reveal paradoxes of a professional practice in face of the predominant nihilism that takes the actors' bodies, in the context defined by Han as "society of the weariness". How to develop resistance movements, where just weariness seems to exist? How to build up escape lines, when everything seems to invite to relinquishment? These are the questions suggested throughout the plot. They call for the analysis of education in times that not only invite to give up, as also incite resistances.

Keywords: Fictional narrative. Nihilism. Resistance. Teaching work. Creation.

\section{RESUMEN}

El artículo intenta resaltar una dimensión sensible de las prácticas educativas, a través de una producción estilizada, no estandarizada, de conocimiento. El texto-guión conduce la creación artística de una actriz, al mismo tiempo que revela el aula escénica donde se realiza la enseñanza, encarnando los dilemas existenciales contemporáneos de trabajar con la educación. El ejercicio de la escritura ficticia, según lo propuesto por Bottoni y Costa, establece la estrategia metodológica que cose el estudio. Esta estrategia tiene como objetivo revelar las paradojas de una práctica profesional frente al nihilismo predominante que toma los cuerpos de los actores, en el contexto definido por Han como una "sociedad del cansancio". ¿Cómo crear movimientos de resistencia, donde parece haber fatiga? ¿Cómo inventar líneas de escape, cuando todo parece invitar a la retirada? Estas son las preguntas sugeridas a lo largo de la trama para analizar la educación en tiempos que no solo invitan a desistir, sino que también incitan a las resistencias.

Palabras clave: Narrativa ficticia. Nihilismo. Resistencia. Trabajo de enseñanza. Creación.

\section{NOS BASTIDORES DE UM INÍCIO}

EU JÁ NÃO AGUENTO MAIS!!! Não tenho mais corpo que suporte carregar o peso desta vida leviana. NÃO! Daqui não passo, nem mais um passo! Mas [. . .] Farei o que mesmo? Não mais atuar?

\section{CENA I: DE UMA EXISTÊNCIA QUE SE ARRASTA}

E stava perdida. Tantos anos de profissão não acabam com esse eterno não saber o que fazer diante do novo papel a ser desempenhado. Não era mais jovem, mas também não era uma senhora. "Não há nada mais mal definido do que uma mulher de meia-idade", pensava consigo. 
Era atriz. Sentia-se dona do espetáculo quando estava em cena. Mas, de repente, não sabia dramatizar neste agora. Perdida em seus próprios dramas, suas coleções de gestos não bastavam para a nova personagem que a vida lhe impunha e que ela gostaria de poder recusar. Talvez trabalhar, naquele momento, não fosse nada além de uma forma de se dar conta de que era incapaz de trabalhar (Blanchot, 2010) e isso the rendia uma dor tanto desinteressante quanto assustadora.

Encarregava-se dos afazeres diários com questōes em seu pensamento: "Como encenar uma pessoa que nem é velha, nem é nova; nem é gorda, nem é magra; nem é alegre, nem é triste; não é nada especial. É mulher como eu, tem a minha idade. Mas não pode ser eu! Não é extraordinária, é banal. Como tornar o banal extraordinário sem lhe arranjar cacoetes que denotem artificialidade? Como encenar outra eu sem ser eu mesma? Como criar de mim, para além do que sou?".

Era uma profissional ativa, cada vez mais. Só recentemente descobrira que seu funcionamento hiperativo, que tanto lhe rendeu bons frutos, tratava-se de um sintoma. A agenda assoberbada, os atrasos reincidentes, as tarefas sobrepostas já lhe causavam mais constrangimentos do que ganhos secundários de uma atriz requisitada. De repente, já não entendia como, àquela altura da vida, sentia, ainda, essa sensação de incompletude que não lhe dava certezas diante dos desafios. Mantinha-se em constante aperfeiçoamento, em plena produtividade, mas a sensação de incompletude se perpetuava, como se fosse um fantasma que ela precisava exorcizar.

Seguia exigindo uma "postura profissional" socialmente adequada, portandose como uma empreendedora de si. Estava sempre ativa e embrulhava-se na ilusão de que assim era mais livre (Han, 2017). No entanto, a despeito de ilusóes quaisquer, tinha consciência das peculiaridades do seu trabalho. Sabia que uma personagem só "toma corpo" quando seus gestos se imprimem na vida real, de modo a magnetizar o espectador. No teatro, é fundamental que a plateia se conheça e se desconheça, ao mesmo tempo, num movimento incessante de encontros que se dão com as vidas das personagens encenadas. Encenar é, essencialmente, produzir conhecimento e oportunizar a possibilidade de pensar sobre as coisas do mundo (Santana, 2017).

Como pensar sobre aquela meia-vida, naquele corpo de meia-mulher na idade meio-indefinida que o papel lhe atribuía? Não conseguia se ver, neste novo trabalho, pensando sobre o mundo ou sobre sua atuação no mundo. Concomitantemente, esse "não se ver" parecia dizer sobre o espelho do mundo: um vão que não mostra nada, que desfigura o futuro, apaga o passado e, de presente, aniquila o agora. Diante da angústia que o trabalho lhe fornecia (ora 
em doses homeopáticas, ora em turbilhóes de agonia), via somente suas próprias amarras e suas limitaçoes: um corpo que já não tinha mais a mesma potência de antes e um repertório que lhe parecia insuficiente, ainda que renovado pelo constante aperfeiçoamento. Vivia, consequentemente, uma atuação modulada por circunstâncias com as quais ela não sabia lidar. Era como se seu corpo não pudesse suportar qualquer outra história.

Estava cansada. Cansada das avaliações de seus trabalhos e dos trabalhos feitos para contemplar boas avaliações. Às vezes, pensava que "o excesso da elevação do desempenho leva a um infarto da alma” (Han, 2017, p. 71), contudo sentia que precisava positivar tais pensamentos e, por isso, nunca recusava projetos, oportunidades de produzir mais, embora sempre reclamasse da vida. As reclamações em si não lhe pareciam um problema, tinha motivos de sobra para se queixar, mas, mesmo entendendo que existem reclamações analisadoras, não sentia que as suas iriam levá-la a algum lugar. Temia encarcerar-se num circuito lamuriento e evitava, por isso, analisar a questão mais detidamente. Pensava cada vez menos, apenas reclamava do cansaço ${ }^{1}$. Achava que ele é parte intrínseca do trabalho, naturalizando a queixa que se reproduzia, por alimentar o circuito produtor da própria queixa: trabalho-produção-cansaço $=$ mais trabalho, mais produção, mais cansaço..., sucessivamente, sem compreender que "o cansaço, de antemão, já tomou posse do repouso" (Blanchot, 2010, p. 20). "Descansase para se retomar a atividade" (Pelbart, 2016, p. 42) era a fórmula que seu corpo experimentava a cada despertar. Assim, vivia para descansar e, descansada, começava a se cansar novamente, sem nenhum estranhamento dessa experiência, como se, absorvida pelo cansaço, vivesse apenas nele e por meio dele, sem que nenhuma análise pudesse questionar essa vida que se fechava opressiva, como uma conversa infinita com pausas benevolentes e sem sombra de interrupção desse círculo enclausurante (Blanchot, 2010).

Um sonho recorrente assombrava suas curtas noites de sono e acenava que ela se tornava peça de uma engrenagem produtiva e desvitalizada: via-se fazendo seu habitual jogging no parque próximo ao teatro de seus ensaios, aproveitando intervalos para desopilar; repentinamente, seu ato cotidiano se nebulava, e ela percebia que sua pele se recobria de um pelo ralo e malhado, as pernas viravam curtas patas de um animal atrofiado, o verde das árvores a sua volta secavam, deixando de ser natureza para tornar-se uma grande gaiola na qual ela se exercitava ao estilo das rodas de hamsters que se aceleram mais conforme o bicho se move,

\footnotetext{
${ }^{1}$ A expressão do cansaço será sustentada, neste texto, na obra de Han (2017) que dialoga com, porém difere do uso que Deleuze (2010) faz do conceito quando discute a figura do esgotado. Retomaremos essas expressões na cena II do artigo, ao avançarmos com experimentação do cansaço da protagonista. Por ora, cabe delimitar que, para Han (2017), o imperativo da positividade que rege a Sociedade do cansaço produz uma nova paisagem de enfermidades, como a depressão, o transtorno de déficit de atenção com síndrome de hiperatividade (TDAH), ou a síndrome de burnout, cujas raízes estão na vivência de que nada é possivel ante uma sociedade que cultua a crença de que nada é impossivel.
} 
provocando a própria aceleração. Acordava de súbito, às vezes assustada como quem sente gosto de realidade na mais onírica ficção. Às vezes, incomodava-se com o acordar da madrugada, mas se atormentava apenas por ter de voltar a dormir, como obriga a noite de quem tem dias atarefados; fazia do pesadelo um aviso surdo, e o colocava debaixo do travesseiro como punha todas as outras coisas as quais fingia não existir.

De dia, quando fingia que não se importava por dormir pouco, observava seus grupos sociais, e todos lhes pareciam peças da mesma máquina. Chegava a imaginá-los como famílias de hamsters compartilhando as gaiolas-playgrounds montadas para experimentos comportamentais. Nesses grupos, a expressão do cansaço de todos lhe parecia cada vez mais nítida, pois era sinônimo de uma atuação profissional intensa e verdadeiramente produtiva. Não obstante as similaridades entre amigos e colegas, ela se sentia sempre vazia, sempre na iminência de não aguentar mais, sentia-se profundamente só e triste. Tristeza e solidão misturavam-se ao cansaço e à produção, e assim ela seguia.

Até que, entediada do próprio acostumar-se àqueles dias arrastados, ela propôs-se uma experimentação.

\section{CENA II: DO ESGOTAMENTO À PERSONAGEM}

Em sua vivência dramática da ilusória liberdade e sempre em busca do bom desempenho profissional, aceitou um convite para uma oficina de exaustão do ator. Em princípio, julgava estar por demais cansada para se permitir exausta.

No seu cotidiano, a exaustão era o limite temido. Dizer sim à exaustão era como permitir a loucura. Sim, já pensava por meios não racionais. Sim, isso era parte do exercício de criação de personagem, mesmo que sempre tenha havido uma expectativa de razão no insano processo de acolher, em seu corpo, o corpo de outros. Sem análises críticas ou reclamações, saiu de casa para seu experimento, como quem sai e se deixa atrás da porta.

$\mathrm{Na}$ oficina de teatro, a primeira instrução foi fechar os olhos e manter-se em silêncio. A supressão da visão e da fala aboliam também a linguagem usual, suprimiam "esta linguagem que nos aprisiona e sufoca, linguagem repleta de cálculos, lembranças, histórias, significações, intençōes, hábitos” (Pelbart, 2016, p. 44). A partir daí, tudo ficou incerto e sem sentido.

Passou muito tempo no escuro das pálpebras cerradas, mas percebia que era conduzida por uma mão que a levou a outros lugares, até que ela perdesse a noção de onde estava. Caminhando ou parada, ficou tanto tempo sobre seus pés que já não os sentia mais. O desgaste de seu corpo impedia que ela conseguisse 
pensar no sentido que a levou àquela vivência. Naquele espaço, não era mais uma atriz em busca de uma personagem, era um corpo que tentava se sustentar e que, de tanto esgotar suas forças, não tinha outra opção além de se deixar levar pelos acontecimentos.

Ouvia poucas instruções e mal sabia segui-las. A despeito disso, naquele não poder ver, não poder perguntar e não saber o que fazer, algo se processou, e tudo ocorreu sem os vieses de um "certo", um "errado" ou um "deve ser assim". Tudo simplesmente aconteceu. Seu corpo pulava, contorcia-se desengonçado, esgueirava-se por outros corpos, como se o mundo não fosse nada além de um transe sem qualquer sentido ou direção. $\mathrm{O}$ exercício materializava-se por movimentos sem intencionalidade e que se uniam descompassados em todas as variações para fazer sentir que, no esgotamento, combina-se o conjunto das variáveis, inventando possibilidades que não se importam com enquadramentos e finalidades (Deleuze, 2010).

O desgaste era tudo. Não havia tempo para pensar; o desgaste era muito grande. $\mathrm{O}$ corpo fatigado há horas não recebia alimento ou água, mas ela não tinha fome. Se pensasse, saberia da sede, da necessidade de água, mas, assim como nada via, nada sentia, além de um esgotamento que ali era vivido como um cansaço fundamental . Já não era ela, já não era um ser circunscrito a uma categoria delineável, pois, nessa experiência de transe, "o cansaço profundo afrouxa as presilhas da identidade. As coisas pestanejam, cintilam e tremulam em suas margens. Tornam-se mais indeterminadas, mais permeáveis, e perdem certo teor de sua decisibilidade" (Han, 2017, p. 75).

Por um momento, ela abriu os olhos e, nesse instante, viu o teto. O teto estava a dois palmos de distância do seu nariz; só aí percebera que seu corpo estava na horizontal. Estava suspensa. Seu corpo fora carregado sem que ela sequer o notasse. Naquele momento, ela flutuava sem que um movimento intencional a levasse àquela posição, sem que tal posição tivesse argumento em si mesma.

Ela sentia sem pensar e, por isso, talvez tenha sido difícil para a atriz narrar aquele estranho momento sem recorrer a explicações racionais. Tecnicamente, tudo se resumia a um exercício no qual se exige que o corpo do ator seja levado à exaustão, porque daí, e só a partir da experiência desse limite, é que é possível o trabalho de criação das personagens que, posteriormente, tomarão o corpo do ator. Trata-se de uma experiência de permitir que outras formas possam brotar

\footnotetext{
${ }^{2}$ Ressaltamos aqui a torção que o filósofo coreano faz ao defender um cansaço fundamental que, diferente do outro "cansaço", apontado na cena I (que aprisiona os sujeitos à mesmice lamurienta do irrealizável), "Ele inspira" (Han, 2017, p. 73), e não pode ser associado a um estado no qual estamos incapacitados de fazer algo. Esse o conceito que se articula às ideias de Deleuze (2010) sobre o Esgotamento, pois o Cansaço fundamental é a força que inaugura novos possíveis desamarrados de uma identidade programada. Para falar do ponto de virada no qual o que está posto não é mais força restritiva, ambos autores partiram da arte (Deleuze, com a obra Beckett, e Han, da poesia de Handke), o que permite aproximar a vivência do esgotamento, na concepção deleuziana, da experimentação do cansaço fundamental, exaltado por Han.
} 
de si. Para uma atriz, é a possibilidade de compor sua personagem por meio de uma potência que, embora possa ser sentida no seu próprio corpo, está para além de um sujeito. Sentia-se mais leve do que nunca e, sem se aperceber, saiu cantarolando "Se meu mundo cair, eu que aprenda a levitar" (Wisnik, 2011).

Se outrora a atriz não sabia como compor sua personagem, pois isso não lhe parecia possível; agora, a partir da técnica experimentada e para além desta, ela sentia que "o que é possível é criar o possível" (Henz, 2012, p. 19) e, nesse instante, a personagem se fez. Fez-se no voo do corpo esgotado, "pois renunciou a toda necessidade, preferência, finalidade ou significação" (Deleuze, 2010, p. 71).

Já era possível estar em cena, mas o que agora se tornava possível se desconectava do conhecido, tratava-se de "outra modalidade de possível, o possível como o 'ainda não dado', o possível 'a ser inventado”' (Pelbart, 2016, p. 339).

Metamorfoseada no corpo-exaurido que levitou até o limite de sua velha forma para ganhar a força de um corpo disforme que se dispõe à nova personagem, ela entra em cena e se depara com um velho cenário: à sua frente, como metacaminho, a porta (ainda fechada) de uma sala de aula empoeirada. Em suas mãos, uma familiar lista de presenças, a lembrar-lhe que sua plateia se compõe de alunos. A atriz não é atriz de teatros erigidos de cimento. Seu teatro se compõe de múltiplas existências, e seu olho turva sob holofotes de um palco em que a vida não imita a arte, mas exige constituir-se em arte para manter-se vida. Sob seus pés, a forma-atriz traduz os contornos de uma professora que acabara de preparar seu corpo esgotado para nele fazer brotar o corpo docente, personagem que cadencia em sua fala a voz de um coletivo que resiste.

\section{CENA III: DO DESCORTINAMENTO DE UM FAZER PROFESSORAL}

Abriu a porta da sala de aula, e aquilo foi como se um palco se descortinasse, pondo seu corpo diante de um teatro-vida com máxima lotação. À sua frente, alunos-plateia: um corpo discente composto por estudantes ávidos, estudantes desinteressados, estudantes que a examinam, estudantes esperançosos, estudantes que vigiam com olhos de polícia, estudantes em vigília permanente sem velas acesas..., estudantes que com a professora se encontram para aulas a serem vividas como dramas reais, que falam das alegrias e tristezas de todas as partes informes desta peça.

"Atuar nesta profissão me faz pensar que a sala de aula pode ser uma espécie de prisão de amarras invisíveis", pensou nisso por um rápido instante, pois se lembrou de que, às vezes, ao desempenhar esse papel, sentia como se estivesse na 
colônia penal de Kafka, como se estar ali significasse uma condenação inevitável (Kafka, 1996). Ledo engano de pensamento que se vai no instante em que encarna o corpo docente (essa personagem que não é um, senão um heterogêneo). É um uno-milhares. O corpo docente materializa-se quando o cansaço fundamental opera a ruptura que cria possíveis antes inimagináveis. Surge quando se desfazem as amarras do sujeito e a dimensão coletiva rege a criação de novos possíveis. Corporeifica-se para inteirar a máxima "criar é resistir" (Pelbart, 2016, p. 339). Atuando por meio desse coletivo, os gestos compostos por uma "disjunção inclusiva" (Deleuze, 2010) mantêm os opostos e, em vez de tentar controlar a vida (caindo na onipotência em seu avesso), dizem sim ao inesperado da situação (Henz, 2012).

Se, no seu temor de aprisionamento, suas algemas podem ser invisíveis, também podem ser invisíveis as suas armas, favorecendo uma resistência silenciosamente certeira. Sendo corpo docente, a professora-atriz não se sentia na colônia penal de Kafka. Sentia-se o próprio Kafka, que faz do risco iminente sua maior potência, que faz da beira da morte a vida mais produtiva, que faz do que parece o ocaso a porta por onde escapam as maiores letras (Didi-Huberman, 2013).

E, como a vida é real, seu devaneio de entrada foi interrompido por um questionamento sem interrogação:

CORPO DISCENTE (falando como quem profere um culto matinal): Há quem diga que a morte é o absurdo da vida e, por isso, a gente se apequena diante do fim. Isso faz de nós seres insignificantes. A tirania, o fascismo, qualquer idealismo, religião ou crença política, qualquer ideia que formate o futuro é uma farsa inútil diante da realidade, diante da nossa finitude. Mas, se tudo vai ter um fim, não me incomodam as formas de vida que se manifestam neste agora, não adianta incomodar-se com nada, pois não há jeito a dar. Não sei por que tanto esforço diante de uma luta já perdida.

Eu estou aqui, nesse lugar de estudo, só porque me dizem que é melhor viver empregado e, se é para ter um emprego, é melhor que uma instituição de ensino diga ao mundo que estou pronto para trabalhar. Ou seja, o estudo é uma fábrica de possibilidades de fazer dinheiro, e nada tem muito sentido além de buscar uma vida melhor enquanto estou ainda vivo, uma vida melhor é uma vida economicamente ativa, empregada e produtiva, que dá possibilidades de consumo (encerra seu discurso como se sua sapiência lhe rendesse dólares).

CORPO DOCENTE (responde como se falar, dançar e compor fosse tão simples quanto respirar, mas ao mesmo tempo, tão dificil quanto calar, mumificar-se e morrer): Discordo totalmente, embora concorde com uma coisa: acho que é importante destituir as crenças. As crenças servem exatamente para que, a partir 
delas, a gente se desprenda delas, de si e de uma ideia já formatada de mundo. Quando nos sentimos presos, quando (por exemplo, este espaço parece uma prática já pré-formatada) as saídas possíveis devem ser inventadas, porque o novo mundo ainda precisa ser concebido. Então essa sua ideia de "viver melhor" assim como essa sua ideia de uma "educação para o mercado de trabalho" são invenções que aí estão. São "vendidas" como um modo de viver inquestionável, como se fossem a única possibilidade de ocupar a existência. Podemos, por outro lado, entender que tais ideias, de tão velhas, são caducas. Assumir que o modo verdadeiro de olhar para esse nosso encontro refere-se à concepção de que o mercado é a finalidade da educação, constitui uma grande limitação das nossas possibilidades de estar no mundo. Você fala da vida como um campo de disputa, uma batalha. Mas, se for para olhar a vida desse modo, prefiro dizer que a luta só está perdida quando concebemos que o mundo está acabado. E de que mundo estamos falando? Deste que você toma como pronto ou de outro que ainda está por vir?

(o corpo discente esboça retrucar, mas recua, lançando um olhar de quem diz "fale mais sobre isso")

Se, aos olhos de uns, a nossa finitude pode significar um impasse que nos paralisa, a meu ver, pode indicar que o jogo é imprevisível. Se está determinado que uma hora a vida se encerra, só me resta arriscar e me perder no possível, jogar com o acaso para ampliar minhas possibilidades de inventar o que não foi visto. Para isso, é preciso, primeiramente, destituir a crença de que o sofrimento paralisa e impede a vida. O sofrimento é parte da existência e pode ser vivido com alegria, porque a vivência disso ou daquilo me possibilita novas experiências, novas versões de uma vida a se construir. É claro que não estou falando de usar o sofrimento para engendrar uma alegria idiotizada que produz outro tipo de paralisia: um "jogo do contente" que ainda mantém a sensação de que "tudo deveria ser de outro jeito". Parto da ideia de que crenças podem ser destituídas, sugiro que você comece seu processo de destituição agora (Invisível, 2017), exatamente pela crença de que o sofrimento paralisa e nada produz. É o sofrimento que faz Kafka produzir uma literatura menor (Deleuze \& Guattari, 2017), é a desilusão com as instituições que faz de Deligny (2018) um visionário e é a crença na vida que mostra a Canguilhem (2018) a potência das infidelidades do meio.

"A forma pela qual o pensamento vai ao encontro do que busca está ligada, muitas vezes, ao ensino" (Blanchot, 2010, p. 30); mas, citar Kafka, Deleuze e Guattari, Deligny, Canguilhem, Blanchot ou quaisquer outros só tem sentido se você se desprende da ideia de que o estudo e o uso do que se faz dele serve para garantir um espaço no mercado de trabalho. O estudo pode ajudá-lo a pensar o 
próprio mercado, pode ajudá-lo a pensar em outras possibilidades de trabalho e pode, inclusive, questionar o conceito de trabalho como agora foi verbalizado por você, mas pode, especialmente, ganhar importância por não ter nada a ver com isso e por ir muito além disso. Pode ajudá-lo a produzir pensamento! Quando digo pensamento, falo de um movimento que está para além das ideias já cristalizadas (Rolnik, 2018).

CORPO DISCENTE (expressando um tom de dúvida): Não sei se estou convencido. Acho que talvez haja muita teoria sem sentido nesta conversa. Acho que o mundo é conduzido por hipóteses, as mais variadas teorizações. $\mathrm{O}$ cristão pode se manter bom quando fundamenta sua vida na fé, acredito nisso. Ao mesmo tempo, não creio que a religião é obrigatória nesta vida, pois aceito estudiosos ateus que veem na ciência sua nova fé. Contudo eu também disse que, nesta vida, nada adianta muito. Penso que há milhares de estratégias de vida que são absolutamente inúteis! Crendo nisso, eu me limito ao que é possível: só quero viver bem o tempo que tenho e não creio que destruir as coisas pode trazer algum benefício.

CORPO DOCENTE (como quem faz um adendo ao que disse antes): Eu ainda não falei de destruir. Falei em DESTITUIR. Há aí uma diferença que não é sutil, embora a destruição seja igualmente necessária. Mas... deixando isso em suspenso. Gostaria de ouvir mais sobre essa "fé" que norteia suas aspirações.

CORPO DISCENTE (continuando sua explicação): Eu não disse que tenho fé, só acredito que, nos tempos de hoje, para ser feliz, é preciso dançar conforme a música. E a música, para mim, é o mercado. Eu preciso cumprir as regras para alcançar meu lugar ao sol; só isso importa. Na busca de uma garantia para morrer bem, tenho de seguir adquirindo conhecimentos e habilidades que façam de mim um talento de empregabilidade inquestionável, tenho de seguir empreendendo, preciso fazer de mim o mais atraente dos produtos. Assim, não posso aceitar suas ideias; se fosse possível destituir o mercado, nada me restaria! Seria como matar Deus para o cristão. Seria como roubar do homem de conhecimento toda a crença no que ele já sabe. Dói-me pensar nisso, isso seria cruel! Você não sofreria se fosse destituído todo o conhecimento que você usa em suas aulas?

CORPO DOCENTE: Possivelmente. Entretanto, se eu tivesse de me manter presa ao saber que já conheço, ao formato de trabalho que já me acostumei, sem possibilidades de criação e mudanças, não teria somente uma aula segura, mas uma jaula incomensurável. As desestabilizações são parte de qualquer trabalho; do meu também! E já lhe disse que é preciso entender que o sofrimento não é "o mal" a ser evitado a qualquer custo, aliás, ele é inevitável por ser parte da vida, e esse sofrimento, sobre o qual você fala, poderia ser experimentado como 
a travessia para outra forma, ainda não conhecida, de viver a profissão. Não afirmo, com isso, que esse seria um processo vivido sem quaisquer tipos de dores. Entretanto tais vivências, como disse, são peças de todas as profissões, nós nos constituímos das cenas que se inscrevem no cotidiano profissional e por meio das marcas que tais passagens deixam nos corpos.

Quando você me diz, por exemplo, que é preciso dançar conforme a música, você fala da música e da dança como se fossem regras que, hierarquicamente, sobrepóem-se. Sugiro, todavia, que você pense a dança e a música num plano estético, como criações. Pense na arte em vez do mercado de arte, em vez da indústria cultural. Pense na arte como criação de potência desterritorializante (Rolnik, 2018), uma força que não limita, mas, em contrapartida, expande. Pense numa música que inventa passos de dança, força o corpo a movimentar-se, mas, ao mesmo tempo, cria novas cadências, "re-arranja-se" nesse movimento.

CORPO DISCENTE: Pensar nessa fluidez absurda me angustia. Isso me deixa sem esperanças. É como se a vida não tivesse mais finalidade nenhuma, é como se tudo estivesse desarticulado e disforme, sem qualquer unidade, como se nenhuma máxima fosse verdade. Como se tudo fosse pura criação efêmera de nós.

CORPO DOCENTE: E não é?!

CORPO DISCENTE: Não sei se consigo viver assim...

CORPO DOCENTE: Assim como?

CORPO DISCENTE: Assim, sem um ideal a ser alcançado! Eu preciso saber que estou seguindo o caminho certo para uma vida plena.

CORPO DOCENTE: E o que seria uma vida plena?

CORPO DISCENTE: Essa que eu desejo ter.

CORPO DOCENTE (como quem sabe exatamente o que é querer uma vida que não é a sua, mas se esgotou neste querer, até esgotar este querer): Entendo... Mas você já considerou que expectativas transcendentes (como uma vida ideal, em um mundo ideal) são exatamente aquilo que fomenta o padrão de lamentações nos grupos subjetivados por essa lógica de niilismo passivo? (Paulon, 2006). Afinal, esse ideal transcendente, ascético, perfeito, sempre em conformidade, de fato, não tem nada a ver com a vida. Ao contrário disso, ele destoa da vida e reclama por uma experiência em que a vida (em sua singularidade disforme, caótica e imprevisível) é anulada. Queixar-se da vida em função de um ideal inventado, que em nada se refere ao dia a dia que de fato é vivido, significa estar à espera do que não vem. Isso é a vida que você deseja ter? 
CORPO DISCENTE: Não. Não falo do que não vem. Falo do que pode vir a ser.

CORPO DOCENTE: Independentemente de qualquer coisa, tudo pode vir.

CORPO DISCENTE: Isso sim! A vida é imprevisível!

CORPO DOCENTE: Concordo tanto com isso que creio ser bobagem préformatar sua existência em razão de "uma vida que quero ter" inventada por alguém que nem é você.

CORPO DISCENTE: E o que você propõe?

CORPO DOCENTE: Propor? Sei lá se eu tenho o que propor, no máximo, eu diria que ME proponho a viver o instante. Amor Fati, diria Nietzsche! "Amar e mudar as coisas, me interessa mais [. . .]" (Belchior, 1976).

CORPO DISCENTE: Ah, bonito! Mas como se faz isso?

CORPO DOCENTE: Diga-me você.

CORPO DISCENTE: Eu?

CORPO DOCENTE: Sim! Quem mais para tomar o SEU destino em suas mãos?

CORPO DISCENTE: Palmas à professora!!! Posso supor que o seu discurso está muito bem embasado teoricamente, entretanto, para ter essa garantia, preciso que você assuma seu papel! Se considerarmos a etimologia das palavras "professor" e "aluno", entenderemos que sua função seria se dedicar àquele que cresce (Houaiss \& Villar, 2001). Nesse sentido, cumprir sua função significaria que você estaria a nos mostrar o caminho da verdade, não é mesmo?!?! (pergunta aguardando uma resposta afirmativa)

CORPO DOCENTE: Não. Não é!

CORPO DISCENTE (confuso): Agora eu me perdi! Essa conversa não é para me convencer de alguma coisa?!

CORPO DOCENTE: Não, não é!

CORPO DISCENTE (ainda mais confuso): Como assim?! Ainda estou certo de que seu papel aqui é repassar teorias e mostrar que você sabe mais que todos nós.

CORPO DOCENTE: Até pode ser se pensarmos que me cabe mostrar o que já se cristalizou em termos de conhecimento. Mas, para além disso, é também parte da minha tarefa me misturar com você até que a gente se perca. Até quando alguém, escutando-nos, não consiga identificar quem ensina e quem aprende, 
porque não há um limite que define claramente cada papel. É como se a plateia deixasse de ser espectadora e se tornasse protagonista. Como se as forças de um fora de nós pudessem borrar aquele que um dia pensamos ser.

CORPO DISCENTE (agora visivelmente irritado): Aham! Quem ouve você assim até pensa que está na frente de uma atriz encenando a peça da boa professora. Eu duvido que você me convença de que essa sua prática não é, no fim das contas, um doutrinamento.

CORPO DOCENTE (entre a paciência e o deboche): Agora vejo algo em que podemos concordar mais uma vez! Se tomarmos a vida como produção estética, criação e arte, tudo que falamos poderia ser uma peça de teatro e toda professora seria, de certo modo, meio atriz, assim como outros trabalhadores quaisquer. Mas isso é bem diferente de concordar que querer compartilhar os saberes acumulados pela humanidade seja o mesmo que querer convencê-lo de que é certo o que está nos livros. Por isso mesmo me vejo muito mais como uma desarrumadora de doutrinas do que uma doutrinadora qualquer.

CORPO DISCENTE: Só posso dizer que agora piorou tudo e acho que essa conversa vai dar um nó nas minhas ideias. Parece que cada vez que chegamos a um ponto em comum, ele nos escapa, já nem sei o que tinha entendido. Para mim, é um alívio não me importar com aquilo que não posso mudar! Por isso, eu escolho manter o foco em minha vida profissional para não enlouquecer de tristeza, pois não pode ser bom ver tudo de ruim que há no mundo.

CORPO DOCENTE: Sua concepção de mercado e sua relação com ele podem impedi-lo de sucumbir ao desespero, eu entendo...

CORPO DISCENTE (falando como quem quer provocar e como quem se sente provocado): Às vezes, até parece que você concorda com o próprio inimigo.

CORPO DOCENTE: Mas de que serve um inimigo se não para provocar em nós uma análise de nossos limites? Talvez precisemos desejar inimigos cada vez mais potentes, "sede de inimigos, resistências e triunfos" é a marca dos espíritos fortes, como nos ensina o filósofo do martelo (Nietzsche, 1998, p. 36).

CORPO DISCENTE: Presumo que só um louco acha bom ter inimigos. $\mathrm{E}$ eu, de fato, penso que, sem uma bússola que norteie um caminho, viver é enlouquecedor.

CORPO DOCENTE: Pode ser que ter o mercado como guia, como você sugere, impeça-o de morrer, mas isso também o impede de viver.

CORPO DISCENTE: Como assim? (retruca espantado)

CORPO DOCENTE: Nunca lhe ocorreu trocar o sonho de um "mundo 
melhor" pela possibilidade de construir novos mundos? Não valeria a pena revirar o que hoje se avalia como "bom" e "mal" para pensar uma vida com novos valores? Não seria interessante, em vez de adotar um novo salva-vidas (como o mercado), suspender as convicções sobre o porvir para assumir a concretude de fazer do AGORA um presente que vale a pena? Afinal, quantos sujeitos dedicados a esse "mercado", sobre o qual você fala, já sentem que alcançaram o "lugar ao sol"? Nem sei se o sol existe nessa busca desenfreada por uma vida de plenitude.

CORPO DISCENTE: É claro que soa atraente essa história insana de fazer JÁ o que eu, de fato, acho que importa numa vida que vale a pena ser vivida. Conheço um monte de gente correndo atrás do futuro que não chega, nesse embalo de "empreendedor de si" (Han, 2017), cada vez mais distante das metas milionárias e intangíveis que se colocam para aquilo que definiram por felicidade. Mas também é meio assustadora essa exigência de me colocar como responsável por tudo que minha vida pode ter de melhor e pior a cada instante. Você podia, ao menos, dar uma pista de como se põe isso em prática, senão é só loucura!

CORPO DOCENTE: Talvez, enlouquecer seja uma pista.

CORPO DISCENTE (admirado): Ah, bom! Essa resposta agora só pode ser para me enlouquecer de vez! (pausa) Mas o pior é que até faz sentido. Só louco para escolher levar a vida, com a intensidade de seus acontecimentos, como se não houvesse amanhã. Bem cantava o grande Renato Russo. Aliás, eu estou começando a acreditar que vocês poderiam concordar neste ponto:

É preciso amar as pessoas

Como se não houvesse amanhã

Por que se você parar pra pensar

Na verdade não há (Russo, Villa-Lobos, \& Bonfá, 1989)

Não era assim a música?! Acho que estou doido misturando a música de minha adolescência com a filosofia de minha vida adulta!

CORPO DOCENTE: Enlouqueçamos então!!!

CORPO DISCENTE: No fim, acho que talvez você tenha razão nessa sua lógica inventada. Mas ainda acredito que você só quer me convencer de que eu estou errado.

CORPO DOCENTE: Nos termos de nossa conversa, "certo" e "errado" também devem deixar de ser formas acabadas. Música da adolescência e filosofia 
da vida adulta não precisam ser categorias excludentes. Nesse sentido, em um diálogo em que se perder se torna uma possibilidade, poderíamos "concluir" que eu também quero aceitar a possibilidade de experimentar equívocos.

CORPO DISCENTE: Só faltou dizer que é melhor ser aluno do que ser professor.

CORPO DOCENTE: Melhor seria dizer que não há sentido em ser professor sem que seja possível sentir-se aluno quando se ensina! Sendo corpo docente, quero aprender a desaprender. Não haveria criação do novo sem um esgotamento das velhas formas impressas neste corpo.

CORPO DISCENTE (não convencido, porém pensativo): Se eu fosse professor e me desse conta de que meus alunos podem saber mais do que eu, de que a sociedade pode bradar que meu valor é ínfimo e de que eu tenho de inventar todos os dias novas formas de trabalhar, eu me sentiria permanentemente no "fundo do poço".

CORPO DOCENTE: O "fundo do poço" me possibilitou assumir outras formas de superfície, nas quais vertical e horizontal não têm nenhum sentido. Esgotar-me no "fundo do poço" me foi absolutamente necessário, uma etapa fundamental do processo que viabiliza, inclusive, esta conversa.

CORPO DISCENTE (como quem chega a uma triste conclusão): Isso me fez pensar no quanto estudar é doloroso. Estudar dói tanto que faz os professores (supostos estudiosos) chegarem ao "fundo do poço"!

CORPO DOCENTE (rindo-se): O processo de estudo nunca é fácil, mas recompensa quando desemboca numa criação.

CORPO DISCENTE: E esse processo se dá aqui, na sala de aula? $\mathrm{Na}$ biblioteca? Entre os livros?

CORPO DOCENTE: Sim e não! Meu trabalho só realmente acontece quando esta conversa deixa de ser uma tarefa e passa a ter sentido para além deste teatro. Sófocles não teria qualquer sentido se mantido entre as paredes fechadas de um teatro. A emoção de qualquer Antígona se atualiza quando, em nossas vidas, a tragédia opera em nós transformações corriqueiras, tão sutis que não podemos nos aperceber delas. Por isso, está na hora de pôr reticências nesta conversa e deixar que nossos corpos sigam para o indeterminado.

CORPO DISCENTE (ainda provocador): Ah, tá! Parece até que essas palavras carregam um prazer quase sádico em evitar ideias plenas, aquelas de que justamente preciso para garantir uma boa nota nas provas. Parece até que me deixar em dúvida é um desejo secreto. 
CORPO DOCENTE: Garanto que de secreto esse desejo não tem nada! Suportar a dúvida é condição para inventar suas respostas ou boas perguntas. Além do mais... Prova? O que é uma avaliação de curso diante das provações da vida? Dizem que estou em avaliação todos os dias, e eu me angustio por ter dúvidas, mas continuo reinventando-me, porque tais dúvidas existem.

Sugiro que nós, múltiplos de um só corpo, escapemos desta sala, deste cenário, deste papel, desta tela fosca... Qualquer espaço fechado, para nós (corpos docentes e discentes) assume ares de cubículo. Embora a vida se faça em qualquer espaço, para mostrar a vida ao mundo, é preciso derivar a céu aberto.

CORPO DISCENTE: Então vamos! Quem sabe a gente se acerta neste desacerto?

CORPO DOCENTE: Ou se desacerta neste acerto!

CORPO DISCENTE: Vou cantar "Alucinado", anunciando que "A minha alucinação é suportar o dia-a-dia. E meu delírio é a experiência com coisas reais" (Belchior, 1976).

\section{NOS BASTIDORES DO SEM FIM}

E onde o delírio sonhou ser sala de aula, a porta se abriu e se fechou, deixando um silêncio muito pouco vazio, enquanto uma multidão saía pelos buracos de fechadura. No teatro da vida, professoras que fingem atuar agradecem a todas as plateias: as que riem e as que choram. As plateias, por sua vez, aplaudem o que acham sublime e vaiam o que lhes desagrada. Quando voltam para suas casas, elas se esquecem de que, gostando ou não, o espetáculo sempre lhes afeta e o maldito se repete quando alguém conta à vizinha a repulsa que certo texto lhe causou.

Na música, não sabemos se a casa da atriz é de louça, se é de éter, se é loucura ou se é cenário. Mas "para sempre é sempre por um triz" (Hollanda \& Lobo, 1982), pois ser feliz tem de ser perigoso. Afinal, é sempre assim, quando a ficção é usada como uma lupa que exaspera o invisível para disparar novas realidades (Bottoni \& Costa, 2018), descortinando caminhos para experimentar até que tudo se esgote novamente e surja aquilo que nós ainda não podemos descrever. 


\section{REFERÊNCIAS}

Belchior, A. C. (1976). Alucinação. (faixa 6). Rio de Janeiro: Polygram.

Blanchot, M. (2010). A conversa infinita 1: a palavra plural. A. Guerra Neto (Trad.). São Paulo: Escuta.

Bottoni, F. D., \& Costa, L. A. (2018). Ética ficcional-cartográfica: a procura humilde e a força frágil. Quaderns de Psicologia, 20(1), 89-100. Recuperado a partir de https://doi.org/10.5565/rev/qpsicologia.1436

Canguilhem, G. (2018). O normal e o patológico. M. T. R. C. Barrocas (Trad.) (7a ed.). Rio de Janeiro: Forense Universitária.

Deleuze, G. (2010). Sobre o teatro: um manifesto de menos: o esgotado. F. Saadi, O. Abreu, \& R. Machado (Trads.). Rio de Janeiro: Zahar.

Deleuze, G., \& Guattari, F. (2017). Kafka: Por uma literatura menor. C. V. da Silva (Trad.). Belo Horizonte: Autêntica.

Deligny, F. (2018). Os vagabundos eficazes: operários, artistas, revolucionários: Educadores. M. Miguel (Trad.). São Paulo: N-1.

Didi-Huberman, G. (2013). Diante da imagem. P. Neves (Trad.). São Paulo: Editora 34.

Han, B.-C. (2017). Sociedade do cansaço. E. P. Giachini (Trad.). Petrópolis: Vozes.

Henz, A. de O. (2012). Estéticas do esgotamento: extratos para uma politica em Beckett e Deleuze. Porto Alegre: Sulina; Editora da UFRGS.

Hollanda, C. B., \& Lobo, E. (1982). Beatriz. Rio de Janeiro: Som Livre.

Houaiss, A., \& Villar, M. S. (2001). Dicionário Houaiss da lingua portuguesa. Rio de Janeiro: Objetiva.

Invisível, C. (2017). Motim e destituição agora. São Paulo: N-1.

Kafka, F. (1996). Na colônia penal (5a ed.). São Paulo: Paz e Terra.

Nietzsche, F. (1998). Genealogia da moral: uma polêmica. P. C. Souza (Trad.). São Paulo: Companhia das Letras. Recuperado a partir de https://doi.org/978$85-7164-823-4$ 
Paulon, S. M. (2006). A desinstitucionalização como transvaloração: apontamentos para uma terapêutica ao niilismo. Athenea Digital: Revista de Pensamiento e Investigación social, 1(10), 121-136. Recuperado a partir de https://doi.org/10.5565/rev/athenead/v1n10.296

Pelbart, P. P. (2016). O avesso do niilismo (2a ed.). São Leopoldo: N-1.

Rolnik, S. (2018). Esferas da insurreição: notas para uma vida não cafetinada. São Paulo: N-1.

Russo, R., Villa-Lobos, D., \& Bonfá, M. (1989). Legião Urbana: Pais e filhos. In Quatro estaçôes. (faixa 2). Rio de Janeiro: EMI.

Santana, C. A. (2017). Poética do drama e esclarecimento: Diderot, teatro e educação. A Palo Seco, 9(10), 94-101.

Wisnik, Z. M. (2011). Se meu mundo cair. In Z. M. Wisnik. Indivisivel. São Paulo: Circus. 